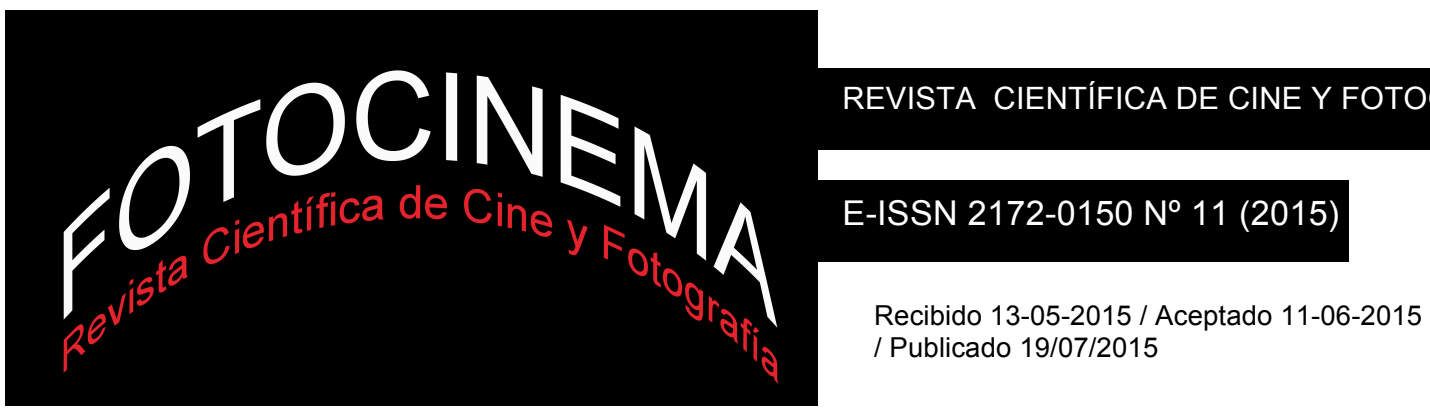

\title{
EL HECHIZO DE LAS IMÁGENES: BLANCANIEVES, EL CUENTO ESPECTACULAR DE PABLO BERGER (2012)
}

\author{
THE SPELL OF THE PICTURES: BLANCANIEVES, PABLO \\ BERGER'S SPECTACULAR TALE (2012)
}

\author{
Diane Bracco \\ Université Paris 8 (Laboratoire d'Études Romanes), Francia \\ dianoletta@hotmail.fr
}

\section{Resumen:}

En 2012 se estrena el segundo largometraje del director español Pablo Berger, Blancanieves, adaptación cinematográfica del cuento popular basada en la versión escrita de los hermanos Grimm. La originalidad de esta transposición estriba en la opción por parte del cineasta de rodar una película muda y en blanco y negro, en la que propone además una hispanización de la historia original. El presente artículo pretende examinar los resortes de este cuento en imágenes contemporáneo cuyo autor elabora una poética de la exhibición que actualiza el carácter espectacular y el poder hipnótico del cine primitivo. Se analizarán las distintas declinaciones de la dialéctica del mostrar y del ver, piedra angular de una estética que recicla los tópicos de la españolada, a la par que recoge la tradición de los circos de monstruos y el legado del cine mudo como arte de la ilusión. Más allá de los espectáculos que se despliegan dentro de la diégesis, es la propia película la que genera un metadiscurso sobre la naturaleza mostrativa de la imagen cinematográfica y, por tanto, puede ser considerada como un homenaje a las fantasmagorías del séptimo arte.

\begin{abstract}
:
In 2012, the Spanish film-maker Pablo Berger directed Blancanieves, cinematographic adaptation of the popular tale based on the Brothers Grimm's written version. The originality of this transposition lies in the director's choice of making a black-and-white silent film in which, moreover, he proposes a hispanisation of the original story. The present article aims to examine the resorts of this contemporary tale in pictures whose author elaborates a poetics of monstration that actualizes the spectacular character and the hypnotic power of primitive cinema. We will analyse the different declinations of the dialectic of exhibition and contemplation, cornerstone of an aesthetics that recycles the topics of the españolada and combinates them with the heritage of freak shows and the legacy of silent cinema as an art of illusion. Beyond the shows that take place in the diegesis, the film generates a metadiscourse about the monstrative nature of the cinematographic picture and, consequently, can be considered as a hommage to the phantasmagorias of the cinema.
\end{abstract}

Palabras clave:

Blancanieves; Pablo Berger; cuento de hadas; espectáculo; mostración; espectralidad

\section{Keywords:}

Blancanieves; Pablo Berger; Fairy Tale; Show; Monstration; Spectrality 


\section{L'ENVOÛTEMENT PAR L'IMAGE: BLANCANIEVES, LE CONTE SPECTACULAIRE DE PABLO BERGER (2012)}

\section{Résumé:}

En 2012 sort sur les écrans le second long-métrage du metteur en scène espagnol Pablo Berger, Blancanieves, adaptation cinématographique du conte populaire basée sur le récit scriptural des frères Grimm. L’originalité de cette transposition repose sur le choix du réalisateur de tourner un film muet en noir et blanc, dans lequel il procède en outre à une hispanisation de l'histoire originale. Le présent article se propose d'examiner les ressorts de ce conte en images contemporain dont l'auteur élabore une poétique de l'exhibition qui actualise le caractère spectaculaire et le pouvoir hypnotique du cinéma primitif. Nous analyserons les différentes déclinaisons de la dialectique du montrer et du voir, pierre angulaire d'une esthétique qui recycle les topiques de l'espagnolade, tout en recueillant la tradition des foires de monstres et le legs du cinéma muet comme art de l'illusion. Au-delà des spectacles qui se déploient au sein de la diégèse, c'est le film lui-même qui génère un métadiscours sur la nature monstrative de l'image cinématographique et, par là même, apparaît comme un hommage aux fantasmagories du septième art.

Mots clés: Blancanieves; Pablo Berger; conte de fées; spectacle; monstration; spectralité

\section{Introducción y metodología}

"Nunca antes te contaron el cuento así..." Esta indicación paratextual que aparece en la contraportada del DVD de Blancanieves recalca de entrada la singularidad de la reinterpretación del célebre cuento de hadas entregada por Pablo Berger en su segundo largometraje, estrenado en 2012. Desde los títulos de crédito iniciales, se presenta la cinta como una adaptación de la versión de los hermanos Grimm que, con Charles Perrault, contribuyeron a fijar la tradición oral de los cuentos populares mediante la escritura. Bruno Bettelheim subraya el doble carácter ancestral y transnacional de dicha tradición, recordando, a propósito de Blancanieves: "es uno de los cuentos más famosos. Se contó durante siglos, en diferentes versiones, en todos los países y todas las lenguas de Europa"1 (Bettelheim, 1976, p. 297). Con el advenimiento del séptimo arte, el relato escrito produjo una amplia descendencia cinematográfica, en parte tributaria de las fuentes

\footnotetext{
1 Traducción de la autora.
} 
iconográficas que son las ilustraciones de los libros de cuentos. El ejemplo más mentado es sin duda el largometraje animado de Walt Disney, Blancanieves y los siete enanitos (1937), antecedente sutilmente convocado por la obra del director bilbaíno y que hunde sus propias raíces en la película muda en blanco y negro de James Searly Dawler, Blancanieves (1916)². Pero la transposición de Berger se distingue de las otras relecturas fílmicas del cuento puesto que estriba en una elección doblemente atrevida por parte del cineasta: la de rodar, en el siglo XXI, un largometraje mudo, en blanco y negro, en el que la matriz cuentística es además objeto de una hispanización. El filme, considerado por algunos críticos en España, como "una de las películas más sorprendentes de los últimos tiempos” (Belinchón, 2013), tarda ocho años en ver la luz, debido sobre todo a la reticencia de los productores españoles. Si la idea del proyecto es muy anterior al estreno de la película muda francesa The Artist (2011), Pablo Berger, lejos de sentirse adelantado, considera que el éxito estrepitoso del largometraje de Michel Hazanavicius favoreció la recepción y exportación de Blancanieves ${ }^{3}$. A pesar de que su obra gozó de un prestigio internacional menor, logró seducir al público y a la crítica, consiguiendo una multitud de recompensas y nominaciones, tanto en España como en el extranjero4.

Este trabajo no pretende analizar la operación de translación en sí, aunque el estudio comparativo del relato escrito y de la versión de Berger revela una interesante transgresión de los contenidos simbólicos y de las figuras arquetípicas del cuento maravilloso, tal y como los define Vladimir Propp5. Se trata más bien de interrogarse sobre la manera como el cineasta explota las potencialidades mostrativas de la imagen cinematográfica, valiéndose de la película muda como espacio de experimentación estética y narrativa, a fin

\footnotetext{
2 Aparece en los extras que vienen con el documental dirigido por Samuel Doux, en el DVD Il était une fois... Walt Disney. Aux sources de l'art des studios Disney, editado a raíz de la exposición homónima presentada en el Gran Palacio de París (16 de septiembre de 2006 15 de enero de 2007) y en el Museo de Bellas Artes de Montreal (8 de marzo - 24 de junio de 2007).

3 Véase la entrevista a Pablo Berger en el making of de la película ("Así se hizo", extras del DVD).

4 Blancanieves fue premiado en varios festivales (San Sebastián, Cartagena, Dublín...) y recibió, entre otras recompensas nacionales, diez Goyas.

5 Françoise Heitz estudia estos aspectos en un artículo que ha alimentado en parte nuestra reflexión. La autora analiza el filme de Berger a la luz de la doble mise en abyme del relato escrito de los hermanos Grimm y del dibujo animado de Disney (HEITZ, 2013, pp- 213-224).
} 
de elaborar una adaptación original, sin igual en el cine español contemporáneo, un poético cuento en imágenes que nos remite a la naturaleza profunda y a los orígenes del séptimo arte: "No podemos olvidar que el cine es contar en imágenes. [...] La esencia del cine es una mirada, es una acción. [...] No es lo que se dice sino lo que se hace"6, declara Pablo Berger a este respecto. El lenguaje de las palabras, común a la transmisión oral del cuento y a su transcripción, queda relegado a un segundo plano -se reduce a los rótulos insertados en el continuo de las imágenes filmadas- para dar paso a una aproximación visual y espectacular del cuento, donde el director recoge la herencia del cine primitivo y de sus fantasmagorías.

Las nociones de espectáculo y espectacularidad, así como la dialéctica subyacente del mostrar y del ver, se situarán precisamente en el centro de esta reflexión. Nuestra ambición es explorar la galería de corporalidades espectaculares que se ofrecen a las miradas -tanto las de los públicos diegéticos como la del espectador extradiegético-, en particular a través del toreo y del flamenco. Gracias al reciclaje de estos tópicos nacionales, el director plasma una estética de la mostración que mantiene por lo demás una relación estrecha con la tradición de los circos de monstruos y la exposición de lo extraordinario. La propia muerte, que flota por encima de todo el relato fílmico, se impone como puesta en escena eminentemente espectacular. Constituye el punto neurálgico de esas variaciones sobre la exhibición que, en un segundo nivel de interpretación, generan un metadiscurso sobre la naturaleza mostrativa y espectral de la propia imagen cinematográfica.

\section{2. Érase una vez un torero y una cantante de flamenco}

Las imágenes que siguen a los títulos de crédito iniciales inscriben la intriga en un espacio-tiempo inmediatamente identificable por el espectador. Los planos generales liminares plantan el decorado a través de un encadenamiento de vistas de la ciudad de Sevilla, reconocible por sus monumentos emblemáticos -la Torre del Oro, la Giralda, filmada desde el otro lado del Guadalquivir- pero cuyas callejuelas blancas parecen desiertas.

${ }^{6}$ Declaración del director sacada del making of de la película. 
Al intertítulo “¿Dónde está todo el mundo?” responden los fundidos encadenados de imágenes que muestran a los individuos y carruajes acudiendo a La Colosal (F1), plaza de toros donde tendrá lugar la próxima

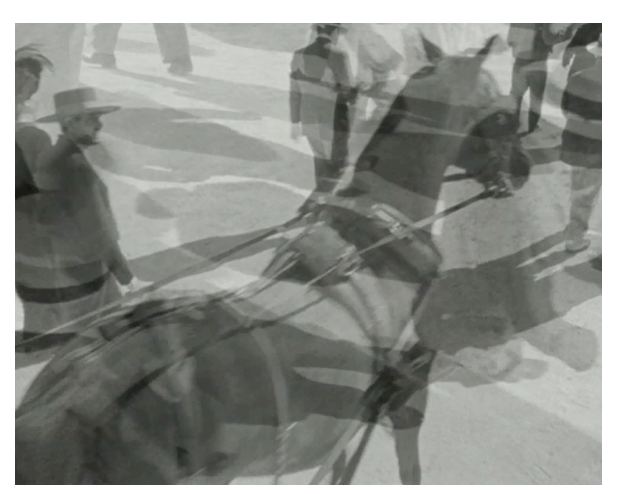
prestación del celebérrimo matador Antonio Villalta, como lo revela a continuación el primer plano de un cartel. El plano de detalle de un billete indica la fecha del acontecimiento, "21 abril 1910”, propiciando la contextualización temporal de la historia.

El motivo tauromáquico y el marco sevillano, con su luminosidad primaveral y mediterránea en las antípodas del ambiente frío y septentrional del cuento original, colocan por tanto de entrada el relato fílmico bajo el signo de una hispanidad exacerbada, rasgo distintivo de una transposición que se arraiga claramente en la tradición de la españolada. En el estudio diacrónico que ha dedicado a los antecedentes y a las declinaciones de este género, José Luis Navarrete Cardero recuerda que el término, en su primer sentido, designa, a menudo de modo despectivo, cualquier obra literaria, musical o cinematográfica que exagera el carácter español de su tema, asimilado, desde la época romántica, con el folclore andaluz. El autor muestra cómo las acepciones del sustantivo se han ido modulando en función de las evoluciones del género y observa, a la hora de la posmodernidad, un remodelado de los tópicos nacionales por el cine español, en un clima creativo marcado por el reciclaje de referencias, la interacción de los lenguajes y el mestizaje de las culturas (Navarrete, 2009, pp. 279-290). Pablo Berger elabora una "post-españolada” en la que se apodera de los clichés heredados de dicha tradición -mezclados al mismo tiempo con referentes extrahispánicos que se estudiarán más adelante- para librarse de la atemporalidad universalizante del cuento de los hermanos Grimm. De este modo, ancla la ficción en una España profunda, atávica e impregnada de religiosidad7 cuyas imágenes evocan tanto la pintura costumbrista de José

7 La iconografía católica desempeña un papel relevante en este retrato cinematográfico de una Andalucía tradicional, tributaria de la españolada, como lo ilustran las secuencias con la abuela, dedicadas a la preparación y a la celebración de la primera comunión de Carmencita. 
Gutiérrez Solana e Ignacio Zuloaga como los clichés en blanco y negro de la España oculta, serie de fotografías realizadas por Cristina García Rodero ${ }^{8}$. Una filiación se impone también a la mente del espectador cinéfilo entre este largometraje mudo y cierta tendencia del cine primitivo nacional (Seguin, 2004, pp. 5-21), representada por películas como Carmen o la hija del contrabandista (Ricardo de Baños y Alberto Marro, 1911), Carmen (Giovanni Doria, 1913) o Sangre gitana (Giovanni Doria, 1913), que explotaron la imagen arquetípica de la España folclórica, forjada especialmente por el romanticismo francés en el siglo XIX. La figura femenina nacida bajo la pluma de Prosper Mérimée aparece en filigrana en la cinta de Berger, a través de los dos personajes significativamente llamados Carmen, personajes cuyo sino está marcado por el sello de la muerte: la esposa de Villalta, artista de flamenco conocida como "Carmen, la de Triana" -en referencia al famoso barrio sevillano-, muere dando a luz tras la trágica lidia que acaba con la carrera de su marido, mientras que su hija fenece en la plaza de toros, varios años después, por haber mordido la manzana envenenada que le regaló la vindicativa Encarna.

La muerte, precisamente, constituye el espectáculo central del cuento visual de Pablo Berger, de la funeste corrida de toros inaugural -con su doble desenlace sangriento revelado mediante el montaje alternado entre las imágenes del parto de Carmen y las de la operación quirúrgica sufrida por Antonio-, a la exhibición pública del ataúd de Carmen-Blancanieves, al final de la película, pasando por la sesión fotográfica en la que participan los allegados de Villalta, posando al lado del cadáver vestido con su traje de luces, y el envenenamiento de la torera prodigio en medio del coso. En otras palabras, el tema macabro es objeto de un proceso de escenificación multiforme en el que el director explota la espectacularidad de los motivos heredados de la españolada, instaurando en particular un diálogo estrecho entre toreo y flamenco. Por una parte, este último puede ser utilizado como

Por lo demás, antes de penetrar en el coso, Antonio Villalta y su hija rezan a la Virgen, en dos pasajes distintos cuyas respectivas construcciones se hacen eco.

8 En diversas entrevistas, Pablo Berger declaró que la estética de la película se arraigaba, entre otras influencias, en esta serie de fotografías y en particular en el cliché de un grupo de bomberos toreros. 
música de fosa9: el aire de flamenco que sucede al pasodoble tocado en la ficción por la orquesta de La Colosal envuelve y dramatiza así parte de la capea final, protagonizada por Carmen, en un pasaje que remite a la secuencia inicial, tanto por su estructura como por la filmación. Los planos generales del ruedo, los primeros planos o planos medios de los espectadores y las imágenes de la lidia propiamente dicha se encadenan frenéticamente, al compás de los acordes de guitarra y de las palmadas, eco sonoro de los aplausos mudos que se ven en la pantalla. Por otra parte, las piezas de flamenco emitidas dentro de la diégesis convocan el recuerdo de la difunta Carmen de Triana cuya voz, inmortalizada en un disco, se escapa de los fonógrafos de la abuela y del esposo nostálgico. Funcionan como un innegable motor narrativo, especialmente en el pasaje del baile desenfrenado en el que el personaje encarnado por Ángela Molina arrastra a su nieta, afectada por la ausencia paterna el día de su comunión (F2), así como en el

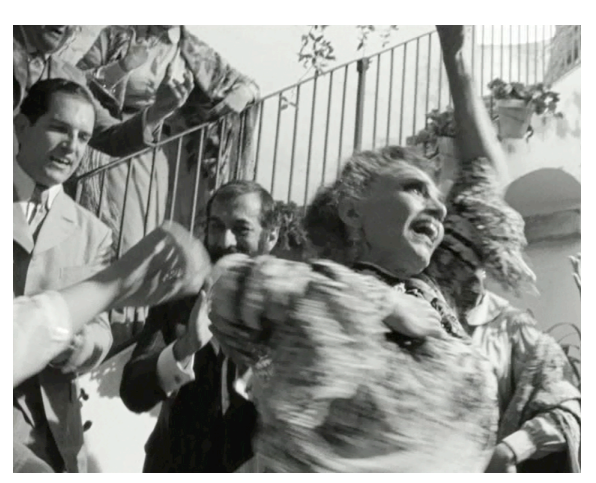
episodio de la sorpresa reservada por Carmencita a su padre inválido. En esta última secuencia, aprovechándose de la ausencia de su cruel madrastra, la niña, vestida de flamenca, surge en la habitación del antiguo torero y baila con él, dándole alegres vueltas a la silla de ruedas, al son de una canción interpretada por su madre. Pero en ambos fragmentos, el torbellino vertiginoso que arrebata a los personajes y al espectador extradiegético traduce un regocijo que no hace más que preceder a la irrupción repentina de la muerte. En el baile improvisado después de la

\footnotetext{
9 En este estudio nos centramos solo en el flamenco. Compuesta por Alfonso de Vilallonga, la música extradiegética, que "salió fundamental" y que Pablo Berger considera como "una de las protagonistas" de su película, merecería un estudio aparte donde se pudieran analizar la manera como el director reactiva las estrategias sonoras desplegadas por el cine mudo (el mickeymousing, por ejemplo) y las funciones originalmente desempeñadas por la música de fosa, que antes se tocaba en vivo en la sala.
} 
comunión, en el momento preciso en que la melodía y la letra se hacen más graves (“por ti moriría, moriría y una y mil veces más”), la abuela, fulminada por un ataque cardíaco, se desploma espectacularmente delante de su nieta y del público formado por sus allegados. En la otra secuencia, la muerte toma los rasgos de la difunta Carmen, que a Antonio se le aparece bailando, cual

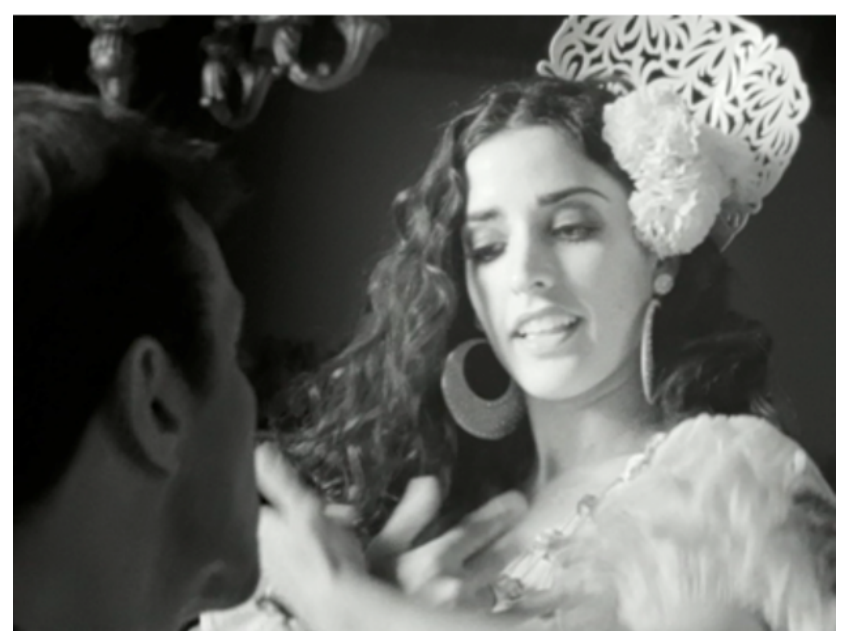
espectro invocado mediante la música (F3). Al mismo tiempo, esta opera como catalizador del odio mortal de la segunda esposa, que ha regresado prema-turamente de una partida de caza: precipita la separación entre el padre y la hija y provoca la muerte de la mascota de Carmencita, el gallo Pepe -matado por los perros de Encarna y servido seguidamente en la cena-, premonición del asesinato posterior de Antonio. Esta concomitancia entre flamenco y tauromaquia es reflejada en parte por el tratamiento fílmico reservado a dichas artes, ambas contempladas por el cineasta como coreografías mortíferas. La perfección del gesto que las caracteriza a las dos es sugerida por una geometría de la circularidad en la que se inscriben las formas redondas del coso, el ojo del toro psicopompo, el altavoz del gramófono y el disco giratorio (su inmovilización marca a la vez el final del baile y la defunción de la abuela), a las que se agrega la rueda (símbolo funesto, asociado con la invalidez del padre y el fallecimiento de la madre ${ }^{10}$, también es una imagen de desplazamiento y movilidad -las ruedas de la caravana de los enanos- y remite a la idea de destino) (Chevalier-Gheerbrant, 1982, pp. 826-830). De manera más general, la isotopía circular abarca motivos que representan a la

${ }_{10}$ Las ruedas de la silla de Antonio responden visualmente a las del carro en el que las enfermeras llevan a su mujer por el largo pasillo del hospital. La cámara, a ras de suelo, sigue al carro y capta el movimiento de las ruedas, evidente símbolo de un hado trágico. 
vez el movimiento continuo y el enclaustramiento11 y cuyos efectos de sentido son redoblados por los movimientos de cámara (las panorámicas vertiginosas en los episodios de cogida y baile, o aquella alrededor de Carmencita, en busca de su gallo en la casa-cárcel de su madrastra) y los procedimientos de transición entre las secuencias (apertura y cierre en iris [F4]; sobreimpresiones de imágenes de redondez, propicias a asociaciones visuales como, por ejemplo, la luna llena-hostia [F5]). Marcado por el retorno final al
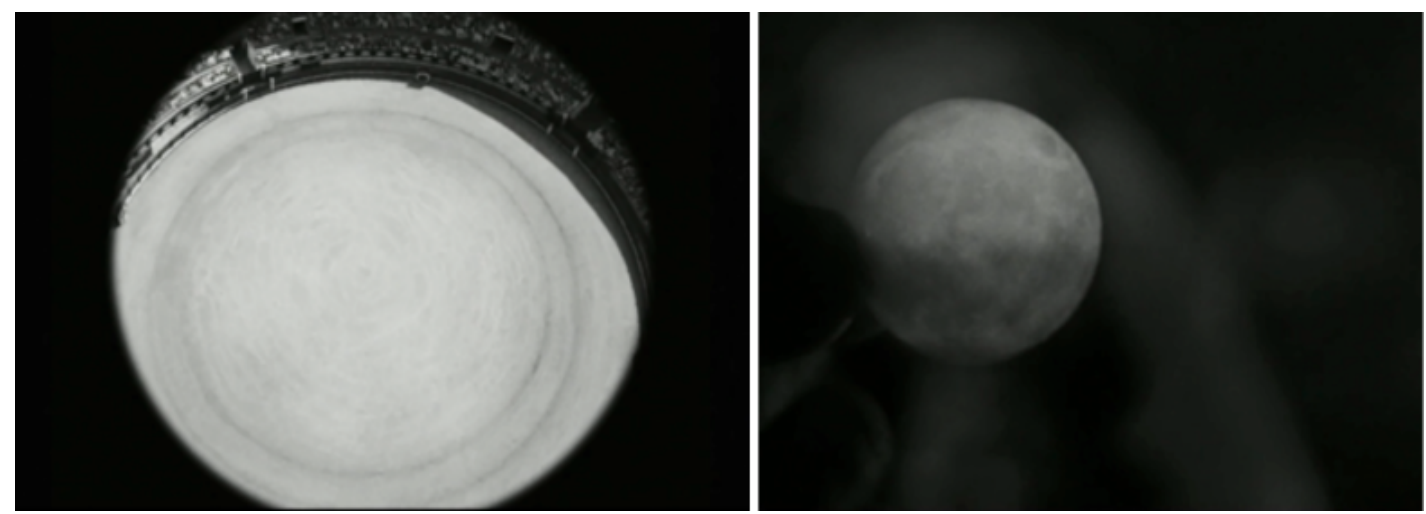

contexto espacio-temporal inicial (La Colosal, un 21 de abril), el propio relato fílmico presenta una arquitectura circular que entra en resonancia con la del ruedo, sugiriendo una muerte programada y espectacular: se abre con la lidia macabra de Antonio Villalta y termina con la de Carmen a cuyo cuerpo sin vida lleva un grupo de espectadores fuera de la plaza de toros, a semejanza de un Cristo crucificado ${ }^{12}$. Es cierto que la heroína triunfa ahí donde su padre fracasó pero no escapa de la venganza de su madrastra y del sueño eterno, como lo confirma a continuación el epílogo en el teatro de tres al cuarto donde se expone su cadáver a la vista de los curiosos.

${ }^{11} \mathrm{El}$ encierro se sugiere asimismo por medio del entrelazamiento de líneas rectas, de formas cuadradas y rectangulares que caracterizan visualmente el territorio de Encarna: las puertas que clausuran los espacios, las persianas y las ventanas cerradas, enmarcadas por cortinas opacas que estorban la circulación de la luz, los paneles de madera, las baldosas, los pilares, las barras de la barandilla y las inmensas sombras rectilíneas que se proyectan en el suelo y las paredes configuran un espacio carcelario, antítesis de la casa abierta y luminosa de la abuela. Otros motivos como la cuna de cristal de Carmencita (anticipación del féretro donde yacerá el cuerpo de la protagonista) o el marco de la ventanilla del coche a través de la cual la niña se despide de su libertad, se inscriben asimismo en esta red visual y simbólica del enclaustramiento.

12 En cierto modo, esta imagen de crucifixión es anunciada desde la primera parte de la película por el plano picado de Carmencita y las demás niñas arrodilladas en la iglesia, durante su comunión. La cámara se sitúa a la altura del inmenso Cristo en la cruz que domina la nave. Se puede considerar este punto de vista como la premonición de un destino marcado por el sufrimiento y la muerte. Es precisamente este día cuando fallece la abuela: el acontecimiento remata el capítulo feliz de la infancia de la heroína, en seguida mandada a casa de su madrastra. Este vuelco narrativo es señalado por la imagen elíptica del vestido de comunión blanco, sumergido en una cuba y teñido de negro. 


\section{Exhibir, mirar: una poética de la mostración}

La escenificación de la muerte como acontecimiento espectacular sirve una escritura cinematográfica de la exhibición fundada en la dialéctica del mostrar y del ver, y polarizada en torno a la mirada. El cuento visual de Berger es atravesado por un tejido de imágenes oculares que hace de la isotopía del ojo un eje estético y narrativo central de la película, hasta el plano final: al término del espectáculo cuyo ápice es la presentación del cuerpo de Carmen, el relato se acaba, tras un lento zoom hacia adelante sobre el féretro de cristal, con el primerísimo plano del ojo cerrado de la heroína, que le desvela al espectador lo que el inconsolable Rafita no ve: a la muerta se le resbala una lágrima por la mejilla después de que el enano enamorado le

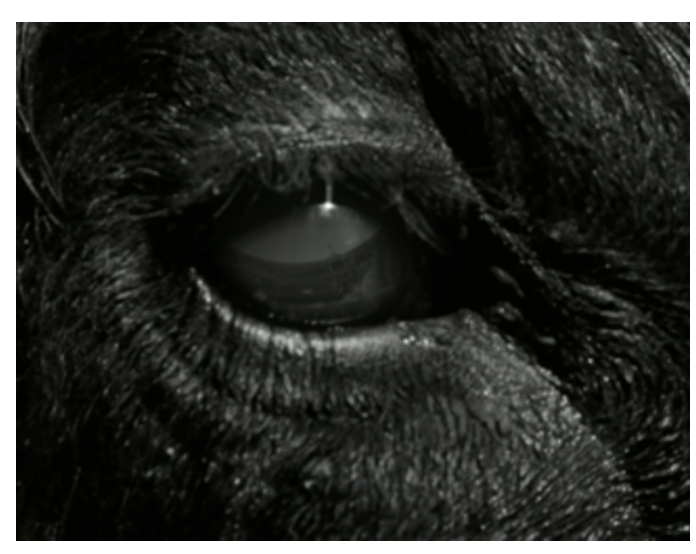
ha dado un beso. Esta pregnancia del órgano de la vista es patente desde el principio de la película, donde Villalta, deslumbrado por el flash de un fotógrafo, no puede evitar la embestida del toro en cuyo oscuro globo ocular se refleja luego el coso, teatro de la trágica caída del matador

(F6). Posteriormente, mientras este le enseña a su hija a torear, le prodiga un consejo que Carmen, amnésica, se rememorará de repente, varios años después, en medio del ruedo: "Nunca dejes de mirar al toro". En la primera parte del filme, es mediante el contacto con esa mirada paterna que se había apartado tristemente de la recién nacida, tras la desaparición de la esposa querida, como se opera, más adelante, el reconocimiento que permite el reencuentro entre el antiguo matador y su hija. En una secuencia ulterior, la focalización de la imagen en el órgano visual induce la asimilación entre las dos encarnaciones de la muerte con las que Carmen tendrá que enfrentarse a lo largo de su existencia: el toro y la madrastra, superponiéndose la mirada de esta al rostro de la niña desafiando a aquel (F7). De hecho es significativo que el flash-back que muestra el asesinato de Villalta, empujado por su segunda esposa escaleras abajo, esté narrativamente enmarcado por dos 
primerísimos planos del ojo de Encarna: el iris del personaje se confunde con el diafragma de la cámara, de tal modo que se producen literalmente una apertura y un cierre en iris, permitiendo la visualización a posteriori de la escena (F8). Estos ejemplos de los usos del ojo como resorte a la vez estético y discursivo evidencian la primacía del ver y del mirar en la escritura elaborada por un director que sondea lo espectacular y se empeña en cernir sus contornos.
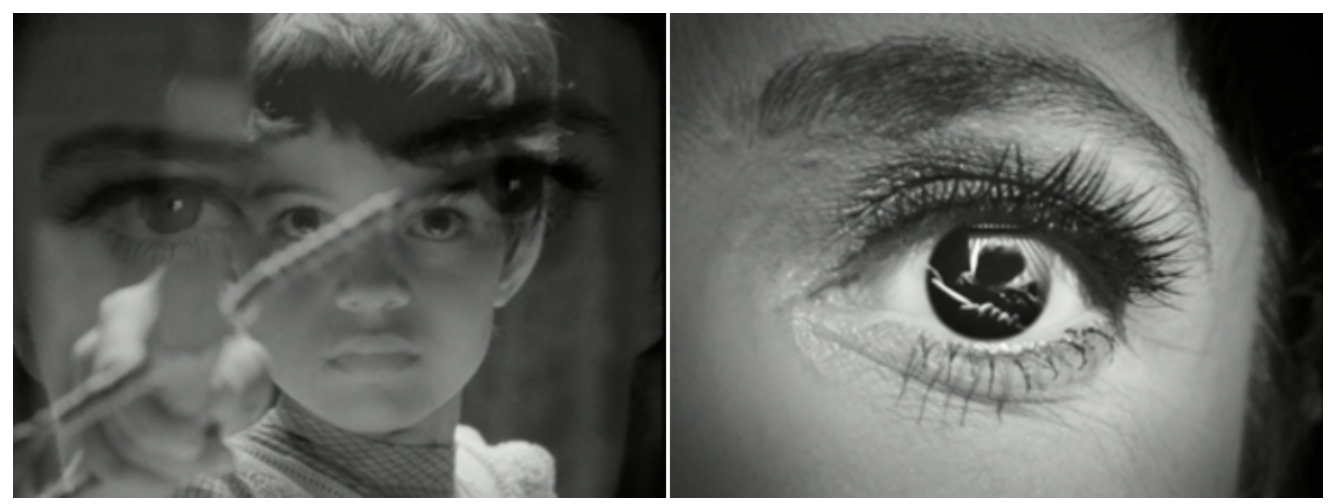

Tal designio pasa también por la constitución de una red de figuras de la exhibición, ofrecidas tanto a las miradas de los públicos diegéticos como a la del espectador extradiegético, red que otorga un papel preponderante a la corporalidad y su escenificación. Representado por el matador en el cénit de su gloria y la joven torera prodigio, el cuerpo triunfante, caracterizado por su perfecto dominio del movimiento y del espacio, objeto de la admiración colectiva, encuentra un contrapunto en los organismos incompletos de los enanos y del torero tetrapléjico. Este último, a merced de su enfermera y segunda esposa, se convierte en el pasto de los periodistas, antes de ser ocultado a las miradas por Encarna, que le condena a la marginalización y al encierro. En cuanto a su caricaturesca carcelera -presentada como la verdadera protagonista de la película13-, forma con el chófer Genaro Bilbao una pareja excesiva, risible, desacreditada por las puestas en escena grotescas de las que Carmencita es el testigo clandestino. Antes de reunirse secretamente con Antonio, la niña espía los retozos sadomasoquistas de Encarna por la cerradura o, escondida en la escalera, asiste a la humillante animalización de Genaro mientras un artista está retratando a su madrastra

${ }_{13}$ "Pieza clave" del relato para Berger, es ella la que aparece en los carteles del filme y el nombre de la actriz que la interpreta, Maribel Verdú, encabeza la lista de los actores en los títulos de crédito. 
dominadora. Por lo tanto, la función del espejo mágico en el cuento original es actualizada, en la cinta de Berger, por los soportes a los que recurre ese personaje megalomaniaco, en constante representación, para inmortalizar su imagen. El narcisismo está reforzado aquí por una búsqueda desenfrenada de visibilidad y renombre, reflejada por las extravagancias de Encarna: sus atuendos exuberantes, las actitudes afectadas que adopta en público, las sesiones fotográficas en las que posa teatralmente, el retrato de tamaño natural, a la medida de su ego hipertrofiado, que le encarga al pintor, o sus tentativas para salir en la portada de una revista cuyos redactores le prefieren finalmente las proezas tauromáquicas de Carmen.

También es preciso prestar aquí especial atención a la pandilla de enanos toreros que recogen a la heroína (ya no son siete, como en el cuento de los hermanos Grimm, sino seis, y son individualizados como en el dibujo animado de Disney). Igual que Encarna, convierten su cuerpo en un espectáculo carnavalesco cuya puesta en escena orquestan pero, a diferencia de la madrastra, ridícula a su costa, no se esfuerzan por idealizar su imagen. Son retratados como saltimbanquis que sacan partido de su singularidad anatómica, bufones deseosos de entretener a un público popular, en las distintas localidades españolas que cruzan. Aparte de las estrategias del disfraz y de la inversión de los géneros (el enano llamado Josefa está maquillado y lleva un vestido de flamenco), el tratamiento deformador aplicado a esta alegre compañía itinerante encuentra su expresión más emblemática en el pasaje de la corrida de toros organizada en la plaza de un pueblo. El episodio reproduce exactamente el desarrollo narrativo de la secuencia inaugural, de la entrada en el ruedo al desenlace trágico (la cogida al torero, pisoteado por el bóvido), tras una fase ascendente coronada por el homenaje que el matador le rinde a una mujer del público (la esposa es aquí sustituida por una burguesa burlona). Pero Berger propone en esta secuencia un espectáculo paródico que patentiza "la debilidad y [...] la disminución humanas"14, históricamente encarnadas por la figura del enano, según JeanJacques Courtine (2005, p. 217). El elegante y peligroso ballet ejecutado por Villalta, frente a los seis toros con los que se enfrenta en el recinto de La

14 Traducción de la autora. 
Colosal, deja paso a un número burlesco en el que tres enanos se enfrentan por turno con una vaquilla. Se filma la triste suerte de Jesusín, el miembro más soberbio de la compañía, según modalidades que recuerdan la sucesión nerviosa, en el íncipit, de planos muy breves -combinados con picado en este caso- que exhiben el cuerpo del torero maltratado como un muñeco de trapo. No obstante, a los planos medios cortos de los espectadores horrorizados y de la esposa que suelta un alarido de desesperación, se oponen aquí los primeros planos de los rostros, grotescamente deformados

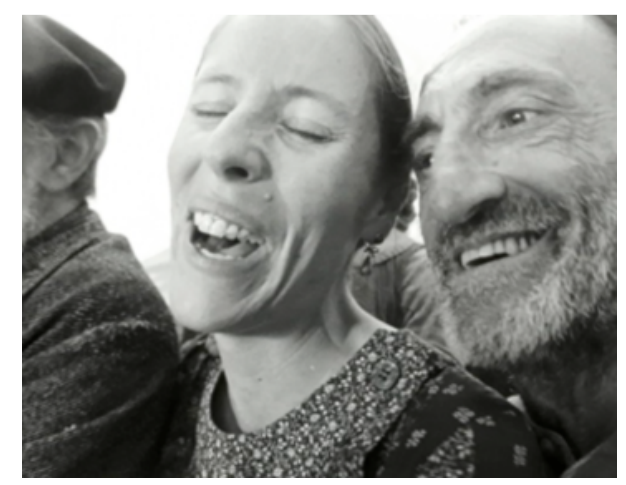
por la hilaridad, de los miembros de una asistencia harto picaresca (F9). En respuesta a la indignación de Carmen, que irrumpe en la plaza para terminar la lidia, con gran perjuicio de Jesusín, un rótulo aparece en la pantalla: "iEsto le encanta a la gente!” Esta explicación suministrada por uno de los enanos, poco sorprendido por la reacción colectiva, nos proporciona una clave de lectura para analizar las declinaciones de la exhibición en el filme, sugiriendo que el acto de mostración pretende ante todo satisfacer las pulsiones escópicas de la audiencia morbosa.

Las risas que provoca en los lugareños la acometida de la que es víctima Jesusín, así como el voyeurismo oportunista del fotógrafo -inicialmente rechazado por el apoderado de Villalta- en la primera secuencia, y la curiosidad de los espectadores que hacen cola para besar a Carmen al final de la película, atañen a la fascinación obscena suscitada por la contemplación del espectáculo de los cuerpos disminuidos y/o agredidos, literalmente extraordinarios. Con esta cuestión del mostrar y del mirar se asoma el tema corolario de lo monstruoso, etimológicamente relacionado con la idea de exhibición: el vocablo procede del latín monere, "avisar" -en la Antigüedad, el monstruo era auguro divino, revelador del destino de la comunidad-, pero también del infinitivo monstrare, "mostrar". En su cuento espectacular, Berger se focaliza esencialmente en esta segunda acepción: se apropia de toda una tradición de la exhibición obscena explorando el régimen de visibilidad de la monstruosidad, la cual reside tanto en el objeto expuesto 
como en el ojo mirón. Los estudios dedicados a la historia del cuerpo definen lo monstruoso como una desviación respecto al estado natural, una categoría que abarca, señala el historiador Alain Corbin, "lo raro, lo inhabitual, lo excepcional"15 (Corbin, 2005, p. 285). La atracción casi universal por las catástrofes de la naturaleza atraviesa las épocas, de los sacrificios catárticos necesarios, en las sociedades antiguas, a la evacuación de los miedos colectivos, a las exhibiciones medievales de monstruos bajo los auspicios de la Iglesia, pasando por las diversiones de Corte ilustradas por los retratos de enanos, obesos y bufones del arte barroco español ${ }^{16}$. El interés pronunciado por las extrañezas y desviaciones orgánicas da lugar, en el siglo XIX, a la aparición de ferias donde se exponen fenómenos vivos y especímenes teratológicos, siendo estas la prolongación de los museos de cera anatómicos, depósitos de cadáveres y cámaras de los horrores, visitados por los mirones en los siglos anteriores (Corbin, 2005, pp. 289-291). Esta práctica popular desemboca en la elaboración de una auténtica industria del voyeurismo de masas cuando Phileas Taylor Barnum funda en 1841 su Museo americano, en pleno centro de Manhattan, y accede a la fama internacional gracias a una gira europea al principio del siglo XX. Convierte al monstruo a la vez en espectáculo y comercio, aliando la tradición de los gabinetes de curiosidades a la de los freak shows. Jean-Jacques Courtine usa la fórmula evocadora de "Disneyland de la teratología"17 (Courtine, 2005, pp. 210-211) para designar el circo Barnum, antecesor del parque de atracciones creado por Walt Disney. La filiación a la que pone de realce esta perífrasis, aparte de una inscripción común en una genealogía de la industria del entretenimiento popular, resulta tanto más significativa, en el caso que nos interesa, cuanto que Blancanieves es el cuento que los estudios Disney escogieron adaptar a la hora de dirigir su primer largometraje, en 1937, extrayendo a la figura del enano del mundo de los freak shows para reciclarla en el universo edulcorado de la película de animación. Si la influencia del dibujo animado es manifiesta en la recuperación de algunos motivos por Berger (la esclavización de la niña por

\footnotetext{
15 Traducción de la autora.

${ }^{16}$ Los enanos toreros de Berger prolongan la tradición pictórica de las anatomías fuera de las normas, preciadas por artistas tales como Diego Velázquez, José de Ribera, Juan Carreño de Miranda o, en el siglo XX, Ignacio Zuloaga. Al respecto, véase Bouza \& Beltrán (2005).

17 Traducción de la autora.
} 
la segunda mujer de su padre, el enano gruñón, la madrastra-bruja), el director recoge ante todo la herencia de Barnum y sus antecedentes feriales. Las hazañas tauromáquicas de los enanos, acompañados por Carmen apodada "Blancanieves" en un juego de mise en abyme del cuento original18_ pueden recordar así el número del "general” Pulgarcito y su ejército, número que marca, para Courtine, "el apoteosis del enanismo", explotado por el empresario americano "que había entendido perfectamente que cuanto más pequeño es el ser, más se le puede ensalzar"19 (Courtine, 2005, pp. 217-219).

El epílogo es sin duda la secuencia de la película que mejor da cuenta de este legado de los circos de monstruos (F10-11). El cuerpo sin vida de Carmen ha pasado a ser la atracción principal de "La Feria de lo Increíble", animada por el mefistofélico apoderado Carlos Montoya de $\mathrm{Val}^{20}$, reconvertido en exhibidor de fenómenos vivos. La exposición de Carmen-Blancanieves constituye el colofón de un espectáculo durante el cual se suceden toda clase
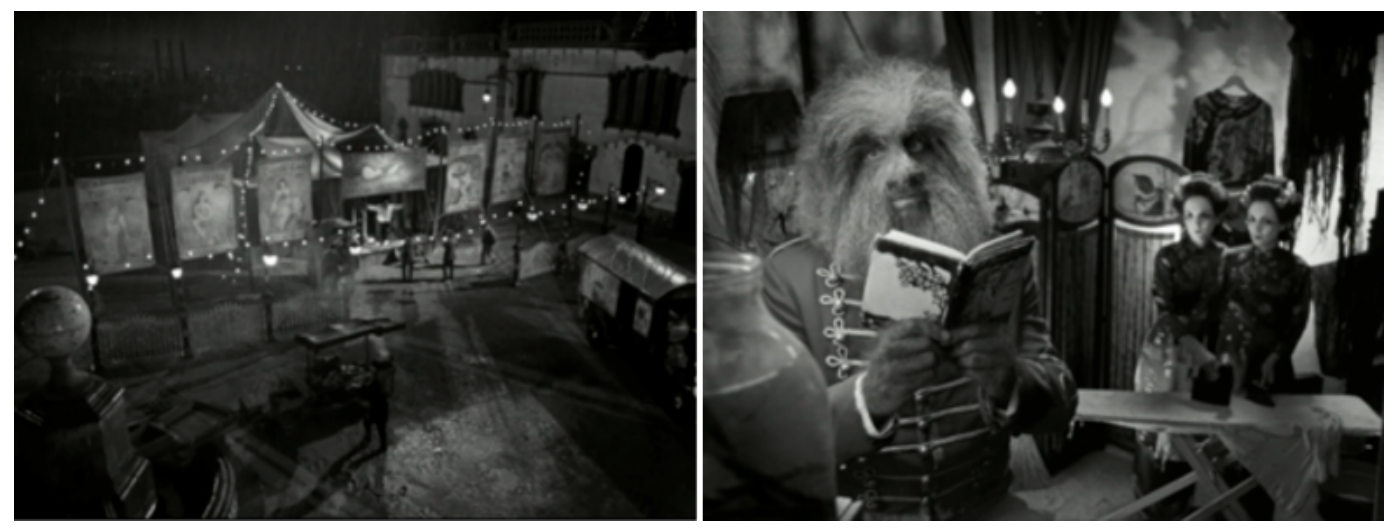

de sujetos marginales, monstruos por exceso (la obesa “Tocino de Cielo"), por defecto ("Paco Flaco y el minúsculo Paquitín”), criaturas dobles (las

18 "Te llamaremos Blancanieves, como la del cuento", le declaran los enanos a Carmen que se olvidó de su nombre. A lo largo del relato fílmico, se pueden detectar varios guiños a otros cuentos de hadas: la lectura de Caperucita Roja revela la relación cómplice que han logrado tejer tardíamente Antonio Villalta y su hija (de hecho, la alusión a los dientes del lobo disfrazado de abuela prefigura, en cierto modo, la triste suerte del gallo Pepe en cuya carne muerde rabiosamente Encarna, durante la cena a la que convida a Carmen, y recuerda las pulsiones caníbales de la madrastra en el cuento de los hermanos Grimm). En la primera parte de la película, la abuela se pica el dedo con una aguja, reminiscencia del íncipit del cuento de Blancanieves (donde es la madre la que se pincha el dedo cosiendo), y quizás también del huso mortal en La Bella Durmiente. Más adelante, Encarna le da un empujón a Jesusín en las gradas de La Colosal y se muestra amenazante: “iTen cuidado, Pulgarcito!”.

19 Traducción de la autora.

${ }^{20}$ Berger retoma el motivo del pacto con el diablo en una secuencia anterior donde Montoya obliga a la joven torera, crédula y analfabeta, a firmar un contrato donde ella se compromete de por vida a cederle sus bienes y ganancias. 
hermanas siamesas) o híbridas (Rintintín, "el niño salvaje, mitad perro, mitad humano")21. Berger actualiza aquí las dos vocaciones espectacular y comercial propias del freak show y consagradas por el circo Barnum: multiplicando los efectos de anuncio grandilocuentes (“¿Milagro o maldición?”, “¿Despertará Blancanieves de su sueño eterno?”) y desvelando de repente el ataúd de cristal donde yace Carmen, Montoya dirige una puesta en escena que intensifica el choque perceptivo y la sideración generados por la vista del cuerpo incorrupto. Al mismo tiempo, al no haber podido adueñarse de las ganancias de la torera, saca provecho de su atracción creando un entretenimiento necrófilo: invita a los espectadores a depositar un beso en los labios de la difunta, a cambio de algunas monedas. Igual que Barnum, maestro de la ilusión y precursor de los efectos especiales, recurre a un trucaje (un muelle colocado dentro del féretro) para simular el despertar de Carmen cuyo cadáver se incorpora bruscamente, provocando el terror de un aspirante príncipe azul que sale corriendo.

Alimentadas en parte por la recuperación de esta tradición de lo monstruoso, las variaciones sobre mostración y voyeurismo convocan inevitablemente algunas referencias cinematográficas tales como Freaks (Tod Browning, 1932) o Elephant Man (David Lynch, 1980). Hito esencial en la historia de las representaciones de lo anormal (Savada \& Skal, 2007, pp. 130-138), la primera aparece en filigrana en varios pasajes, en el excipit desde luego, pero también en el episodio de la fiesta nocturna improvisada por la compañía delante de la caravana, así como en la secuencia de la muerte de Encarna, perseguida por los enanos bajo las gradas de la plaza de toros, al igual que la cínica trapecista Cleopatra es castigada por la monstruosa parada del circo de Browning. El caso es que Blancanieves, más allá de la metamorfosis que el director inflige a la materia cuentística, se puede contemplar como el espacio de un homenaje al arte cinematográfico y a su poder de fascinación, como se verá a continuación.

${ }^{21}$ Usamos aquí la tipología establecida en varios estudios dedicados a la monstruosidad. Véase, entre otras referencias (Fiedler, 1978, pp. 13-36; Garland, 1996). 


\section{De la espectacularidad a la espectralidad: un retorno a los orígenes del séptimo arte}

El desenlace de Blancanieves aclara la dimensión metadiscursiva de un filme que aparece a su vez como un espectáculo, como lo sugieren la imagen liminar de la apertura del telón de teatro y, al final, el primer plano de las palancas que baja Rafita para apagar las luces de la feria (imagen invertida, en cierta manera, de las luces de la sala de cine que se vuelven a encender). La poética de la mostración que domina el relato nos remite a las primicias del propio cine como medio que prolonga el arte ferial de la ilusión. Courtine recuerda a este respecto:

Georges Méliès, cuyo estudio es un laboratorio primitivo de los efectos especiales, proviene del universo de la feria, igual que Tod Browning, que va a asegurar el paso de los trucajes de feria a los artificios hollywoodienses. [...] la feria es la cuna del cine, Hollywood es el hijo natural de Barnum²2. (2005, p. 248).

Pablo Berger pone al día el carácter espectacular del cine primitivo en una película que echa en parte sus raíces en el recuerdo de una proyección del largometraje mudo Avaricia (Eric von Stroheim, 1924), con orquesta sinfónica en vivo dirigida por Carl Davis. Impactado por esa experiencia de juventud, el cineasta se lanzó muy pronto el desafío de realizar a su vez un filme mudo. A la hora de concretar el proyecto, elabora un verdadero himno al séptimo arte, depositario de toda una memoria cinematográfica que el espectador es susceptible de activar, conforme vaya recogiendo las citas sembradas en este "collage" que constituye el relato fílmico, según el director de fotografía Kiko de la Rica ${ }^{23}$. La post-españolada de Berger presenta en efecto un trasfondo referencial plural y transnacional, donde las inspiraciones extrahispánicas que son el expresionismo alemán, el cine vanguardista soviético o la producción hollywoodiense, entre otras, se mezclan con los emblemas culturales españoles estudiados anteriormente. La tipificación de Encarna, por ejemplo, puede remitir a las figuras de mujeres fatales en La Aurora (Friedrich Wilhem Murnau, 1927) -una referencia también convocada por la imagen del estanque neblinoso donde Rafita

22 Traducción de la autora.

23 Véanse las entrevistas a Pablo Berger y a Kiko de la Rica en el making of. 
rescata a Carmen- o Loulou (George Wilhem Pabst, 1929), mientras que la isotopía ocular recuerda inevitablemente el plano del ojo seccionado en Un chien andalou (Luis Buñuel, 1929). Además de estos títulos del cine mudo europeo, se pueden identificar algunas alusiones a las obras de Alfred Hitchcock (los planos del coche que pasa la inmensa reja del Monte Olvido parece ser un guiño a Rebecca, 1940), Orson Welles (la larga mesa que separa a Encarna de Carmencita, durante la cena, evoca de modo bastante obvio Citizen Kane, 1940), Billy Wilder (la imagen del cadáver de Genaro flotando en la piscina procede probablemente de Sunset Boulevard, 1950), pero también posibles influencias de la cinematografía española: Françoise Heitz detecta, por ejemplo, referencias a El espíritu de la colmena (1973) y El Sur (1983) de Víctor Erice, Ana y los lobos (Carlos Saura, 1973) y Journal d'une femme de chambre (Luis Buñuel, 1964) (Heitz, 2014, pp. 213-214). Esta lista no es exhaustiva, ni mucho menos, pero no deja de mostrar que el cine constituye para Berger una fuente de inspiración esencial de su filme ${ }^{24}$, profundamente anclado en la estética fragmentaria y citacionista de la posmodernidad.

Esta celebración del séptimo arte supone en particular un retorno a la prehistoria de la imagen animada y, en este sentido, participa del viaje en el tiempo al que Berger convida a su público, proyectado en un pasado poéticamente convocado por la estética visual del blanco y negro. El director elige significativamente ambientar la ficción en los años 1910-1920, en el momento en que se va desarrollando el cine mudo, y se aplica en recrear una determinada época a la vez que da rienda suelta a la libertad creativa que le otorga la fantasía del cuento. De hecho, su puesta en escena genera un "efecto de realidad" (effet de réel), concepto ideado por Roland Barthes (1968, pp. 84-89), merced a la inserción en el escenario de diversos elementos contextuales -los coches, el dirigible desde el cual se filma La Colosal, el gramófono así como los inventos visuales que son el praxinoscopio y la

24 Es también el caso de su primer largometraje, Torremolinos 73 (2003), comedia cuyo protagonista, Alfredo López, se descubre una pasión por el séptimo arte, en particular por Ingmar Bergman, rodando cortometrajes pornográficos caseros. Parodia y pastiche se entrelazan en esta cinta donde la comedia sexy celtibérica dialoga con el cine de autor, entre otras referencias. De hecho, una secuencia de la película dirigida por Alfredo e insertada en el relato principal anuncia la estética y los personajes de Blancanieves: se trata de un filme en blanco y negro donde ya aparece furtivamente una compañía de enanos toreros. 
cámara fotográfica- que contribuyen a reflejar un periodo marcado por los progresos científicos y técnicos. Aunque la fotografía pertenezca al campo de la imagen fija, merece aquí una atención particular ya que Pablo Berger la incorpora a la materia fílmica, a la vez como operación y resultado, ambos muy presentes a lo largo de la película. El director le confiere una función narrativa (los recortes de prensa conservados en el álbum familiar hojeado por Carmencita nos informan, por ejemplo, de las segundas nupcias de Antonio) a la par que explota su carácter mostrativo (especialmente en los episodios de sesiones fotográficas), poniéndolo al servicio de la escritura espectacular que vertebra el filme. En varias ocasiones, se vale del flash fotográfico y de primerísimos planos de los objetivos como recursos discursivos y estéticos para ritmar una secuencia, creando un efecto estroboscópico $^{25}$ (un ejemplo es la secuencia de la presentación a la prensa del torero inválido, acompañado por su enfermera), o para enfatizar un momento clave del relato y reforzar su sentido. En la secuencia inaugural, se asocian así luz y desgracia: la chispa aciaga que invade fugazmente la pantalla, combinada con el plano de la cogida reflejada en el objetivo del fotógrafo (F12), sugiere el choque fatal entre Villalta y el toro cuyo nombre, Lucifer, "portador de luz", entra en resonancia, en cierto modo, con el arte foto-gráfico como "escritura de la luz" 26.

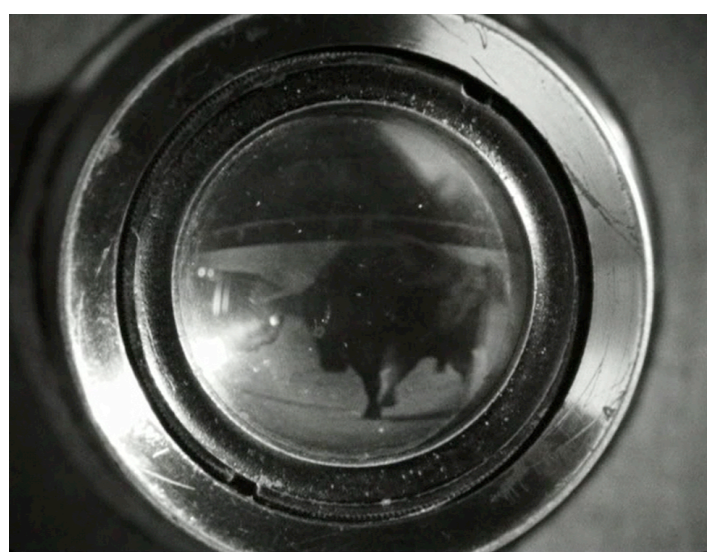

Por lo demás, la naturaleza espectacular de la imagen fotográfica reside en gran parte en el que sea "representación", en el sentido definido por Louis Marin, es decir que "hac[e] presente un objeto ausente"27 (Marin, 1994, p.

25 En otros momentos de la película, son los efectos de luz y contrastes que, conjugados con el ritmo del montaje, producen un efecto estroboscópico. Lo ilustran el episodio de la cogida en la secuencia de apertura, el de la muerte de la abuela, el pasaje donde Genaro intenta asesinar a Carmen en el bosque, y también la secuencia donde la protagonista torea al compás de los recuerdos infantiles que la van asaltando.

${ }^{26}$ De hecho, el matador lleva un traje de luces en el que se ha focalizado la cámara en la preparación anterior de Antonio, mediante primerísimos planos de los distintos miembros del cuerpo del torero. Estos participan al mismo tiempo de una atomización corporal metafórica que anuncia la cogida ulterior y sus dramáticas consecuencias.

27 Traducción de la autora. 
305). Efectivamente, Carmencita no puede sino contemplar las representaciones fotográficas de sus padres, a quienes desconoce, y, más adelante, solo dispone de una instantánea para convocar el recuerdo de Antonio, del que ha sido violentamente separada por su madrastra ${ }^{28}$. En la película, la ausencia está también íntimamente vinculada con la muerte, siendo esta, para Roland Barthes, la esencia misma de la fotografía cuya vocación consiste en reproducir al infinito y de modo mecánico un acaecimiento pasado que no puede volver a ocurrir existencialmente ("esto ha sido”). En su ensayo La Cámara lúcida, el semiólogo así define el espectáculo fotográfico:

El Operator es el Fotógrafo. El Spectator, somos nosotros que consultamos, en los periódicos, libros, álbumes, archivos, colecciones de fotos. Y aquel o aquello fotografiado es el blanco, el referente, especie de pequeño simulacro, de eidôlon, emitido por el objeto, que yo llamaría más bien el Spectrum de la Fotografía, porque esta palabra conserva a través de su raíz una relación con el 'espectáculo' y esto le añade algo un poco terrible que hay en toda fotografía: la vuelta del muerto ${ }^{29}$. (1980, pp. 22-23).

El cineasta explora literalmente este lazo consustancial con la muerte en el episodio de la sesión fotográfica que sigue al asesinato de Villalta. Caricaturiza la antigua tradición de la fotografía post-mortem en una secuencia grotesca, puntuada por los flashes de la cámara, donde la esposa criminal, su amante así como los antiguos compañeros de Villalta, las criadas de la casa y un grupo de lloronas se ponen en escena al lado del cuerpo del difunto, vestido con su traje de luces, frente a un fotógrafo que les ruega que sonrían (F13-14). Solo Carmen, ahora adolescente, derrama lágrimas sinceras cuando viene a posar a su vez en el sofá donde los allegados ridículamente enlutados han abandonado el cadáver.

\footnotetext{
${ }^{28} \mathrm{El}$ inmenso retrato paterno que domina la escalera desempeña una función parecida: nada más penetrar en su nueva casa, Carmencita es fascinada por la representación pictórica de este padre a quien no conoce todavía, aislado en una habitación a la que ella no tiene derecho de acceder.

29 Traducción de la autora.
} 

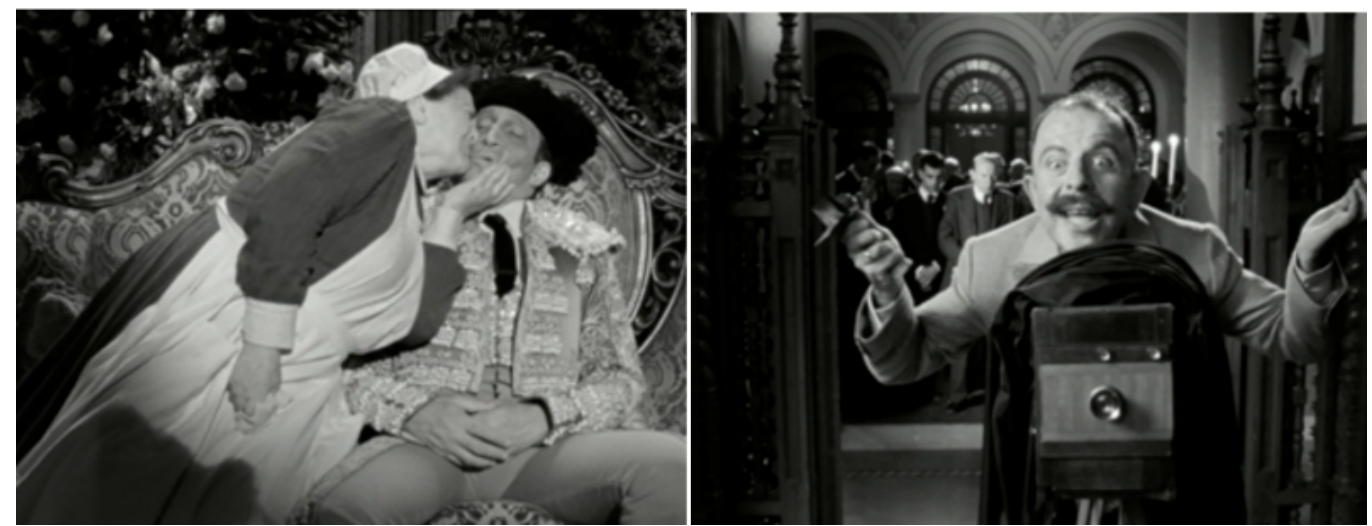

A través de la mise en abyme de la fotografía en esta secuencia fílmica, el cuerpo del muerto queda doblemente expuesto, por una parte al objetivo del fotógrafo diegético, por otra parte a la mirada del espectador extradiegético. Mediante la interacción que se establece así entre ambos medios y el "frente a frente” entre la cámara de cine y la cámara fotográfica, Berger parece sugerir que es el propio espectáculo cinematográfico el que exhibe la muerte y mantiene una relación estrecha con esta, a semejanza de la fotografía. El cliché "embalsama" al sujeto representado y llega a ser su "segunda tumba", escribe Barthes; el cine, por su parte, se caracteriza por la evanescencia de las imágenes que se suceden en la superficie de la pantalla y se impone por tanto como arte espectral. De hecho, se ha subrayado ampliamente la proximidad entre el ritual de la proyección cinematográfica, con su haz luminoso que agujerea la oscuridad de la sala, y una sesión de espiritismo, en la medida en que ambos comparten un intenso poder hipnótico. Berger parece jugar con esta analogía declinando la dialéctica aparición / desaparición a lo largo de su película, por medio de procedimientos fílmicos recurrentes ya mencionados, como el fundido encadenado y la sobreimpresión -muy practicada en el cine mudo-, basados en el doble principio de aparición y desvanecimiento de las imágenes. Hasta el plano de la sábana blanca fantasmal detrás de la que desaparece la heroína niña para dejar paso a una moza veinteañera, atañe a esta retórica de la espectralidad: para formularlo en términos deleuzianos, es a la vez "imagen-tiempo" elíptica, ya que marca simbólicamente el paso de la infancia a la edad adulta, e "imagenmovimiento", dado que evoca tanto la muleta del torero -Carmen se ha ejercitado en la lidia tendiendo la ropa- como la pantalla del cine del que es una evidente metáfora (Heitz, 2014, p. 218). Invita, de forma más general, a 
enfocar la cinta como un espacio habitado por entidades espectrales procedentes de una época remota: los fantasmas de la niñez de Carmen (el gallo Pepe, que aparece en su plato durante una comida con los enanos que reactiva el recuerdo traumático de la cena con Encarna, o su propio padre que le sonríe desde el cielo mientras ella está a punto de enfrentarse con el toro), pero también, en otro nivel de lectura, los de la infancia del propio cine, convocada mediante múltiples reminiscencias fílmicas y visuales. Dicho de otro modo, a través de esta película muda donde el metadiscurso se asoma bajo la reelaboración del cuento de hadas, Pablo Berger se erige a la vez en “cuentista" y "director hipnotizador" 30 capaz de embrujar al espectador para invitarle a remontar el tiempo, actualizando así el poder de encantamiento de un arte balbuceante y eminentemente fantasmagórico.

\section{Conclusiones}

En resumidas cuentas, el examen de las declinaciones de la espectacularidad en Blancanieves nos ha permitido observar los mecanismos de la poética de la mostración plasmada por un cineasta deseoso de hacer interactuar varios legados. Nueva ramificación de la amplia genealogía de adaptaciones generadas por los cuentos populares, su original transposición del relato de los hermanos Grimm conjuga la herencia de la españolada con la tradición popular de los circos de monstruos, a la vez que se nutre de una memoria cinematográfica puesta al servicio de una celebración del séptimo arte. El motivo de la circularidad coloca definitivamente el relato fílmico bajo el signo de la vuelta a un punto de partida, a un estado inicial, metaforizado en la ficción por la resurgencia de los recuerdos infantiles: retorno al pasado contenido en estas distintas tradiciones que se entrelazan y, en particular, regreso a los orígenes de la quimera cinematográfica. Berger se adueña del poder de desestabilización de la mirada propio de las películas "prehistóricas", exhibiendo en la pantalla a criaturas espectaculares, descendentes de las figuras excepcionales de la escena, del circo y de la feria. El toreo cinematográfico de su Blancanieves reactiva así este carácter ilusionista en una obra que sondea el diálogo entre el universo del cuento

30 Véase la entrevista a Pablo Berger en el making of de la película. 
maravilloso y el cine como maravilla -en el sentido etimológico de mirabilis - y arte del hechizo visual.

\section{Referencias bibliográficas}

Barthes, R. (1968). “L’Effet de réel”. Communications, nº 11, pp. 84-89.

Barthes, R. (1980). La Chambre claire. Note sur la photographie, $\mathrm{n}^{\circ} 11$. Paris: Gallimard / Seuil.

Belinchón, G. (2013). "El hechizo mudo y en blanco y negro de 'Blancanieves”". El País [en línea], [s. 1.], Ediciones El País, 15/02/2013:http://cultura.elpais.com/cultura/2013/02/15/actualidad /1360960286_295648.html

Bettelheim, B. (1976). Psychanalyse des contes de fées. Paris: Hachette, col. "Pluriel" (trad. Théo Carlier).

Bouza, F. \& Betrán, José Luis (2005). Enanos, bufones, monstruos, brujos y hechiceros. Marginales. Barcelona: Random House Mondadori, col. "Debolsillo", n 121.

Chevalier, J. \& Gheerbrant, Alain (1982). Dictionnaire des symboles. Mythes, rêves, coutumes, gestes, formes, figures, couleurs, nombres (1969, 1982 édition revue et corrigée). Paris: Robert Laffont / Jupiter, col. "Bouquins".

Corbin, A. (dir.) (2005). De la Révolution à la Grande Guerre, Histoire du corps (vol. 2). Paris: Seuil, col. "L’Univers historique".

Courtine, J-J. (dir.) (2005). Les Mutations du regard. Le XXème siècle, Histoire des corps (vol. 3). Paris: Seuil, col. "L'Univers historique".

Fiedler, L. (1978). "Introductory", Freaks: Myths and Images of the Secret Self. New York: Simon and Shuster, col. "Touchstone", pp. 13-36.

García, R. (2012). "Pablo Berger: 'He mirado al pasado para hacer algo nuevo"”. El País [en línea], [s. 1.], Ediciones El País, 23/o9/2012: http://cultura.elpais.com/cultura/2012/09/22/actualidad/13483384 84_809081html

Garland Thomson, R. (ed.) (1996). Freakery. Cultural Spectacles of the Extraordinary Body. New York: New York University Press.

Heitz, F. (2014). "Au bout du conte... Une Blanche-Neige espagnole (Blancanieves, Pablo Berger, 2012)". Littérature et cinéma : allersretours. Villeurbanne: Orbis Tertius, Hispanística $\mathrm{XX}, \mathrm{n}^{\circ} 31, \mathrm{p}$. 213- $^{-}$ 224.

Marin, L. (1994). De la représentation. Paris: Gallimard.

Navarrete Cardero, J. L. (2009). Historia de un género cinematográfico: la españolada, Madrid: Quiasmo, 318 p.

Savada, E. \& Skal, D. (2007). "La difficile histoire de Freaks" in Risterucci, Pascale \& Uzal, Marcos (dir.), Tod Browning, fameux inconnu. 
Colombelles: Corlet Pulications, col. "CinémAction”, nº 125, pp. 130138.

Seguin, J-C. (2004). “1896-1930. Le cinéma muet”, Histoire du cinéma espagnol (1994). Paris: Nathan, col. "Cinéma. 128”, nº 67, p. 5-21.

Cómo citar: Braco, D. (2015). "El hechizo de las imágenes: Blancanieves, el cuento espectacular de Pablo Berger (2012)". Fotocinema. Revista científica de cine $y$ fotografía, 11, pp. 26-49. Disponible: http://www.revistafotocinema.com/ 